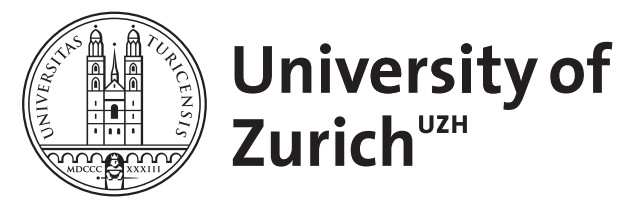

\title{
Expression of visinin-like protein-3 in mouse kidney
}

Pribanic, S ; Loffing, J ; Madjdpour, C ; Bacic, D ; Gisler, S M ; Braunewell, K H ; Biber, J ; Murer, H

\begin{abstract}
In renal proximal brush borders the $\mathrm{Na} / \mathrm{Pi}$ cotransporter $\mathrm{NaPi}-\mathrm{II}$ is part of a heteromultimeric complex including the PDZ proteins PDZK1 and NHERF1, which interact with the $\mathrm{C}$ terminus of NaPiIIa. In this study, a yeast two-hybrid screen against the $\mathrm{N}$ terminus of the $\mathrm{Na} / \mathrm{Pi}$ cotransporter NaPi-IIa was performed. Thereby we identified visinin-like protein-3 (VILIP-3), a member of neuronal calcium sensors. In this study, expression and protein localization of VILIP-3 in the mouse kidney was performed by immunofluorescence and RT-PCR using laser-assisted microdissected nephron segments. VILIP-3 was found to be abundant in distal and collecting ducts where it partly colocalized with calbindin D28K. In addition VILIP-3 was observed in the brush borders of proximal tubular S1 and S3 segments of both superficial and deep nephrons.
\end{abstract}

DOI: https://doi.org/10.1159/000074844

Posted at the Zurich Open Repository and Archive, University of Zurich

ZORA URL: https://doi.org/10.5167/uzh-1375

Journal Article

Published Version

Originally published at:

Pribanic, S; Loffing, J; Madjdpour, C; Bacic, D; Gisler, S M; Braunewell, K H; Biber, J; Murer, H (2003). Expression of visinin-like protein-3 in mouse kidney. Nephron Physiology, 95(4):76-82.

DOI: https://doi.org/10.1159/000074844 


\title{
Expression of Visinin-Like Protein-3 in Mouse Kidney
}

\author{
Sandra Pribanic ${ }^{a}$ Jan Loffing ${ }^{b}$ Caveh Madjdpour ${ }^{a, b}$ Desa Bacic ${ }^{a, b}$ \\ Serge Gislera Karl-Heinz Braunewellc Jürg Biber ${ }^{a}$ Heini Murera
}

Institutes of aPhysiology and ${ }^{\mathrm{b}}$ Anatomy, University of Zürich, Zürich, Switzerland, and ' Institute for Physiology, Humboldt University Berlin, Berlin, Germany

\section{Key Words}

Interacting proteins $\cdot \mathrm{Na} / \mathrm{Pi}$ cotransport $\cdot$ Yeast two-hybrid $\cdot$ Neuronal calcium sensors

\begin{abstract}
In renal proximal brush borders the $\mathrm{Na} / \mathrm{Pi}$ cotransporter $\mathrm{NaPi}$-Ila is part of a heteromultimeric complex including the PDZ proteins PDZK1 and NHERF1, which interact with the $\mathrm{C}$ terminus of $\mathrm{NaPi}-\mathrm{lla}$. In this study, a yeast twohybrid screen against the $\mathrm{N}$ terminus of the $\mathrm{Na} / \mathrm{Pi}$ cotransporter NaPi-lla was performed. Thereby we identified visinin-like protein-3 (VILIP-3), a member of neuronal calcium sensors. In this study, expression and protein localization of VILIP-3 in the mouse kidney was performed by immunofluorescence and RT-PCR using laser-assisted microdissected nephron segments. VILIP-3 was found to be abundant in distal and collecting ducts where it partly colocalized with calbindin D28K. In addition VILIP-3 was observed in the brush borders of proximal tubular S1 and S3 segments of both superficial and deep nephrons.
\end{abstract}

\section{Introduction}

Renal reabsorption of inorganic phosphate (Pi) is a key element in body Pi homeostasis. Thereby, proximal tubular brush border membrane sodium-phosphate $(\mathrm{Na} / \mathrm{Pi})$ cotransport, via the type-IIa $\mathrm{Na} / \mathrm{Pi}$ cotransporter, is the rate-limiting step and the target of physiological/pathophysiological alterations [1, 2; for review see 3].

Yeast two-hybrid as well as biochemical studies suggested that the carboxy terminus of the NaPi-IIa cotransporter can interact with specific PDZ modules of NHERF-1 and PDZK1, which themselves associate with either regulatory or cytoskeletal proteins, or other brush border membrane constituents [4-10]. As for the amino terminal tail of NaPi-IIa, we provided evidence for an interaction with MAP17, a small brush border membrane-associated protein [11]. This interaction seemed to be rather weak and may require additional stabilization via PDZ interaction with PDZK1.

In the present study we have identified visinin-like protein-3 (VILIP-3) as an interaction partner of NaPi-IIa by a yeast two-hybrid screen using the amino terminal part of the cotransporter as a bait. In order to further characterize the functional implications of the observed interaction, we describe for the first time the detailed renal localization of VILIP-3.

\begin{tabular}{ll}
\hline KARGER & ( ) 2003 S. Karger AG, Basel \\
1660-2137/03/0954-0076\$19.50/0 \\
$\begin{array}{l}\text { Fax +4161306 1234 } \\
\begin{array}{l}\text { E-Mail karger@karger.ch } \\
\text { www.karger.com }\end{array}\end{array}$ & $\begin{array}{l}\text { Accessible online at: } \\
\text { www.karger.com/nep }\end{array}$
\end{tabular}

Dr. Jürg Biber

Institute of Physiology, University of Zürich-Irchel

Winterthurerstrasse 190

CH-8057 Zürich (Switzerland)

Tel. +41 16355 032, Fax +41 16355 715, E-Mail JuergBiber@access.unizh.ch 


\section{Experimental Procedures}

Yeast Two-Hybrid Screens and Trap Assays

A whole mouse kidney cDNA library (MATCHMAKER, Clonetech) was screened against the entire $\mathrm{N}$ terminus ( $\mathrm{Nt}$; amino acids 1-109) of the NaPi-IIa cotransporter (Acc. No. AAC52361), as described in detail by Gisler et al. [5] and Pribanic et al. [11]. Several yeast two-hybrid trap assays, confirming the specificity of protein interactions with the NaPi-IIa Nt, were undertaken thereafter. For that purpose, carboxy terminal tail $(\mathrm{Ct})$ as well as the proposed third intracellular loop (ICL-3, amino acids 486-511) [12] of NaPi-IIa were used as bait and tested for interaction. Bait construct of NaPiIIa Ct was used as described by Gisler et al. [5]; the 3rd ICL of NaPiIIa was inserted into vector pBTM116, with three glycines introduced N-terminally.

\section{Immunofluorescence and Western Blots}

Immunofluorescence was performed on adult male mouse (NMRI) kidneys as described [13]. All animals used were kept on a standard diet with free access to tap water. Briefly, 5- $\mu$ m thick cryosections were incubated with the following primary antibodies: either affinity purified or non-purified rabbit anti-rat VILIP-3 (1:500) [14], mouse anti-calbindin D28K (1:10,000, Swant, Switzerland). Prior to immunostaining with the anti-VILIP-3 antibody, some sections were treated with $1 \%$ SDS for $10 \mathrm{~min}$ at room temperature [15]. Binding sites of the primary antibodies were revealed with $\mathrm{Cy} 3$-conjugated donkey anti-rabbit (1:1,000 for VILIP-3), or FITC-conjugated goat anti-mouse (1:40 for calbindin D28K). The secondary antibodies were from Jackson Immuno Research Laboratories (West Grove, Pa., USA).

For detection by Western blotting, $50 \mu \mathrm{g}$ of purified mouse proximal tubular brush border membranes [16] were separated by $12 \%$ SDS-PAGE gels, transferred to nitrocellulose membranes and processed as previously described [17]. The blots were incubated overnight at $4{ }^{\circ} \mathrm{C}$ with primary antibodies (VILIP-3 or NaPi-IIa [17], both 1:3,000) and subsequently with secondary HRP-coupled IgGs (Amersham Pharmacia Biotech). Immunoreactivity was visualized by enhanced chemiluminescence (Pierce). Specific antigen-blocked anti-NaPi-IIa [17] and anti-VILIP-3 [14] gave no significant signal in control experiments.

\section{Laser Microdissection and Real-Time PCR}

Kidneys of 3 adult male mice (NMRI) were snap frozen in liquid nitrogen and $6-\mu \mathrm{m}$ thick sections were cut on a cryostat and mounted on polyethylene membrane slides (Molecular Machines \& Industries, Zürich, Switzerland) and processed as described (Madjdpour et al., submitted). S1 and S3 segments of both superficial and juxtamedullary nephrons and distal tubules were identified by phase-contrast microscopy. A total area corresponding to $100,000 \mu \mathrm{m}^{2}$ ( $\left.\pm 1 \%\right)$ was microdissected for each sample.

RNA was extracted using the Absolutely RNATM Nanoprep Kit (Stratagene, Europe) following the manufacturer's instructions. Firststrand cDNA synthesis in a reaction volume of $50 \mu \mathrm{l}$ was made from total RNA using TaqMan Reverse Transcription Reagents (Applied Biosystems, Rotkreuz, Switzerland) with random hexamers exactly according to the reverse transcription protocol (http://home.appliedbiosystems.com).

Relative quantitation of VILIP-3 mRNA was done using the ABI PRISM 7700 Sequence Detection System (Applied Biosystems) with $\beta$-actin as an internal standard. The sequences of TaqMan probes
(Applied Biosystems, for VILIP-3, and Biosearch Technologies, Novato, Calif., USA, for $\beta$-actin) and primers (Applied Biosystems, for VILIP-3 and Microsynth, Balgach, Switzerland, for $\beta$-actin) were as follows: 5'-(FAM) CAATGATGGCAAACTG (MGB/NFQ)-3' (probe), 5'-TCTTCAGGCAGATGGACACAAA-3' (forward), 5'TTGGCACCTTTGATGAATTCTTC-3' (reverse) for VILIP-3 and 5'-(6-FAM) CCATGAAGATCAAGATCATTGCTCCTCCT (BHQ1)-3' (probe), 5'-GACAGGATGCAGAAGGAGATTACTG-3' (forward), 5'-CCACCGATCCACACAGAGTACTT-3' (reverse) for $\beta$ actin. For both genes primer concentrations were $900 \mathrm{n} M$, and the probe concentration was $250 \mathrm{n} M$. TaqMan probes were chosen to be located across exon-exon boundaries to exclude any amplification of genomic DNA. PCR was performed using TaqMan Universal PCR Master Mix (Applied Biosystems), with a reaction volume of $25 \mu 1$. Reaction conditions were $2 \mathrm{~min}$ at $50^{\circ} \mathrm{C}$ (uracil-N-glycosylase incubation), 10 min at $95^{\circ} \mathrm{C}$ (activation of AmpliTaq Gold DNA polymerase) followed by 45 cycles of amplification $\left(95^{\circ} \mathrm{C}\right.$ for $15 \mathrm{~s}$ and $60^{\circ} \mathrm{C}$ for $\left.1 \mathrm{~min}\right)$. The expression of VILIP-3 and $\beta$-actin was quantitated in separate wells with the respective probe and primers. Relative VILIP-3 expression was calculated with the comparative CT method according to user bulletin No. 2 of the ABI PRISM 7700 Sequence Detection System (available for download at http:// home.appliedbiosystems.com).

\section{Results}

In a yeast two-hybrid screen of a whole mouse kidney cDNA library, using the amino terminal tail of the NaPi cotransporter NaPi-IIa as bait, two clones with a $100 \%$ identity to 'visinin-like protein-3' (VILIP-3),'neuronal visinin-like 3' (NVP-3) and 'hippocalcin-like 1' (Acc. No. NP-057886), were identified. As in yeast trap assays performed with the carboxy terminus or with a cytoplasmic domain (ICL-3) [12] of NaPi-IIa we could not observe any interactions (data not shown), we concluded that the interaction of VILIP-3 with the $\mathrm{N}$ terminus of NaPi-IIa as observed in yeast was specific.

VILIP-3 was originally described as a member of the VILIP subfamily, and belongs to neuronal calcium sensors (NCS) $[14,18]$. Previous studies demonstrated that VILIP-3 is most abundantly expressed in cerebellum, and plays a putative role in intracellular signal transduction [14, 18-20]. Although VILIP-3 was reported to be weakly expressed in the Western blot of a kidney homogenate [14], its detailed renal distribution has not been investigated so far. This prompted us to perform a more detailed study on the renal expression of VILIP-3.

By immunofluorescence, VILIP-3 was observed in proximal and distal tubular segments as well as in glomeruli (fig. 1,2). Overall, no evidence for an intra- or internephron heterogeneity for VILIP-3 was documented (data not shown). In cryosections, which were not pretreated with $1 \%$ SDS (fig. 1), intense VILIP-3 immuno- 
Fig. 1. Immunohistochemical detection of VILIP-3 protein in mouse kidney. Overview picture of mouse kidney cryosections stained for VILIP-3 (a, c) and calbindin D28K (CB28k; b, d), without SDS pretreatment. VILIP-3-specific immunostaining was detected in the distal nephrons (D), thick ascending limbs $(\mathrm{T})$, connecting tubules $(\mathrm{CN})$ and collecting ducts (CD), as well as in glomeruli (G). A weak signal could also be observed in the apical pole of proximal tubules (P). VILIP-3 colocalization with calbindin D28K was seen in the distal tubules, connecting tubules and collecting ducts. $\mathrm{MD}=$ Macula densa; $\mathrm{V}=$ vein .
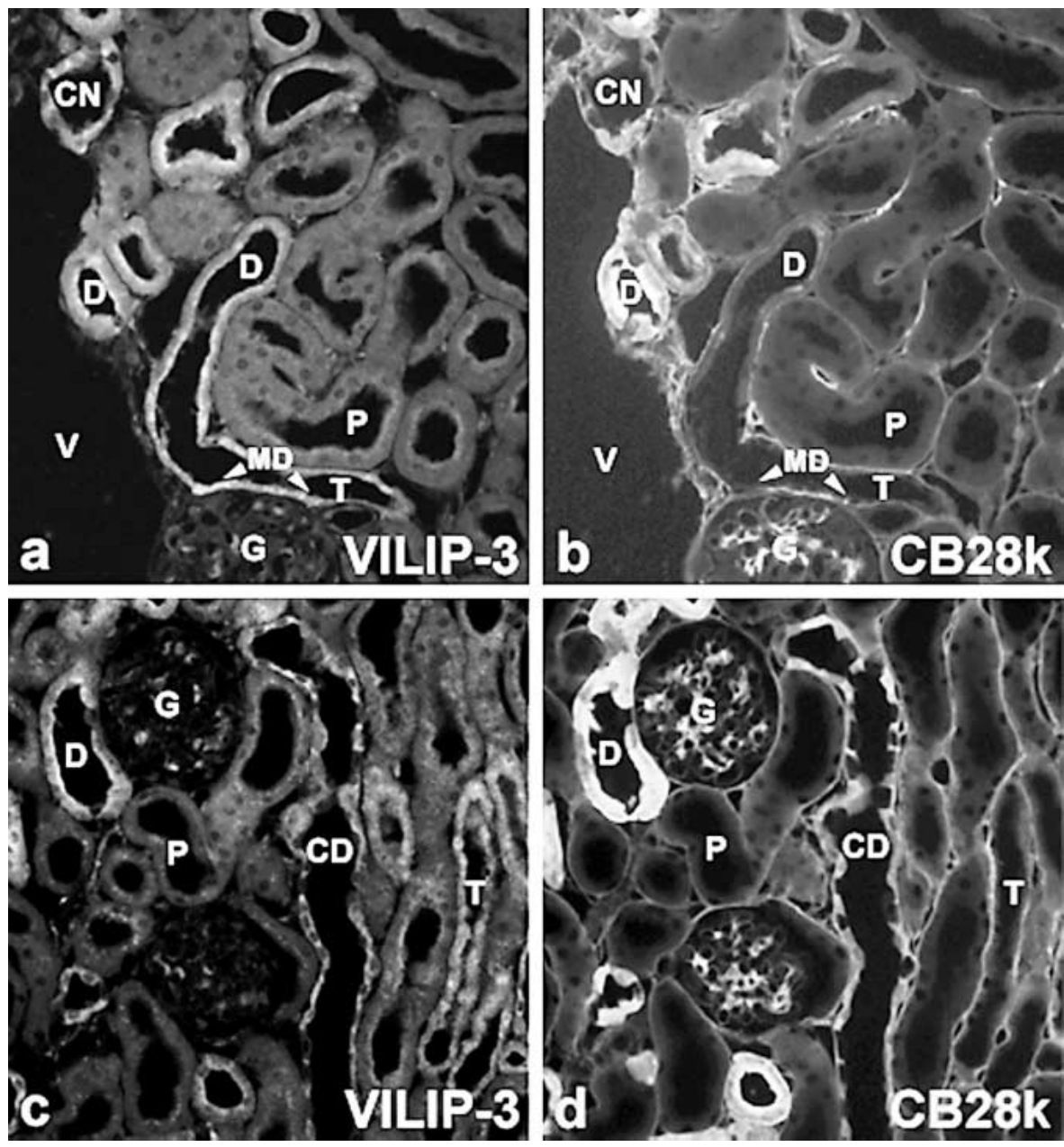

staining was seen along the distal nephrons, including the thick ascending limbs, connecting tubules, and collecting ducts (fig. 1a, c). In proximal tubules a weak signal was observed at the apical pole. Consecutive cryosections were also immunostained for the calcium-binding protein calbindin D28K. Colocalization of calbindin D28K was observed in distal tubules, connecting tubules and collecting ducts but not in proximal tubules (fig. 1b, d).

In order to document the cellular localization of VILIP-3 in proximal tubules in more detail, cryosections were treated with $1 \%$ SDS (antigen retrieval) prior to the incubation with the primary antibody. Most interestingly, in contrast to distal tubules where VILIP-3 was diffusely distributed throughout the cytoplasm (fig. 2a), in proximal tubules VILIP-3 immunoreactivity was observed at the apical pole (fig. $2 \mathrm{a}$ ) and was associated with the brush borders (compare fig. 2c with 2d). Brush border localization observed by immunofluorescence was verified by West- ern blots using isolated proximal tubular brush border membranes. In these membranes, which also contained NaPi-IIa [17], VILIP-3 was detected as a single band at $22 \mathrm{kD}$ (fig. 3).

Expression of VILIP-3 mRNA was analyzed in S1 and S3 proximal tubular segments of superficial and juxtamedullary nephrons and distal tubules which were obtained by laser-assisted microdissection. Real-time PCR clearly showed the presence of VILIP-3 mRNA in all of the isolated segments (fig. $4 \mathrm{a}, \mathrm{b}$ ). The relative comparison of VILIP3 mRNA to the content of $\beta$-actin mRNA demonstrated that no significant differences in the abundance of VILIP-3 mRNA existed between the different proximal tubular segments. It is of note that for $\beta$-actin almost identical $\mathrm{Ct}$ values were obtained in all proximal tubular segments. In distal tubular segments, similar abundance of VILIP-3 mRNA as in proximal tubules was observed. 
Fig. 2. Immunohistochemical detection of VILIP-3 protein after SDS pretreatment. After pretreatment with $1 \%$ SDS, VILIP-3-specific signal was detectable at the apical pole of proximal tubuli (a). Higher magnification (c) and differential interference contrast (d) show clear brush border membrane localization of VILIP-3. In contrast to the proximal tubular localization, in distal tubuli VILIP-3 was distributed cytoplasmatically (c, d). Cryosections incubated with the secondary antibody alone are shown in $\mathbf{b}$. $G=$ Glomerulus; $\mathrm{P}=$ proximal tubule; $\mathrm{D}=$ distal tubule; $\mathrm{CN}=$ connecting tubule; DIC $=$ differential interference contrast; $2^{\circ} \mathrm{Ab}=$ treatment with the secondary antibody alone.

Fig. 3. Immunoblot for VILIP-3-purified mouse proximal tubular brush border membranes were separated by SDS-gel electrophoresis and immunoblotted for the $\mathrm{NaPi}$ cotransporter NaPi-IIa and VILIP-3.

Renal Expression of VILIP-3
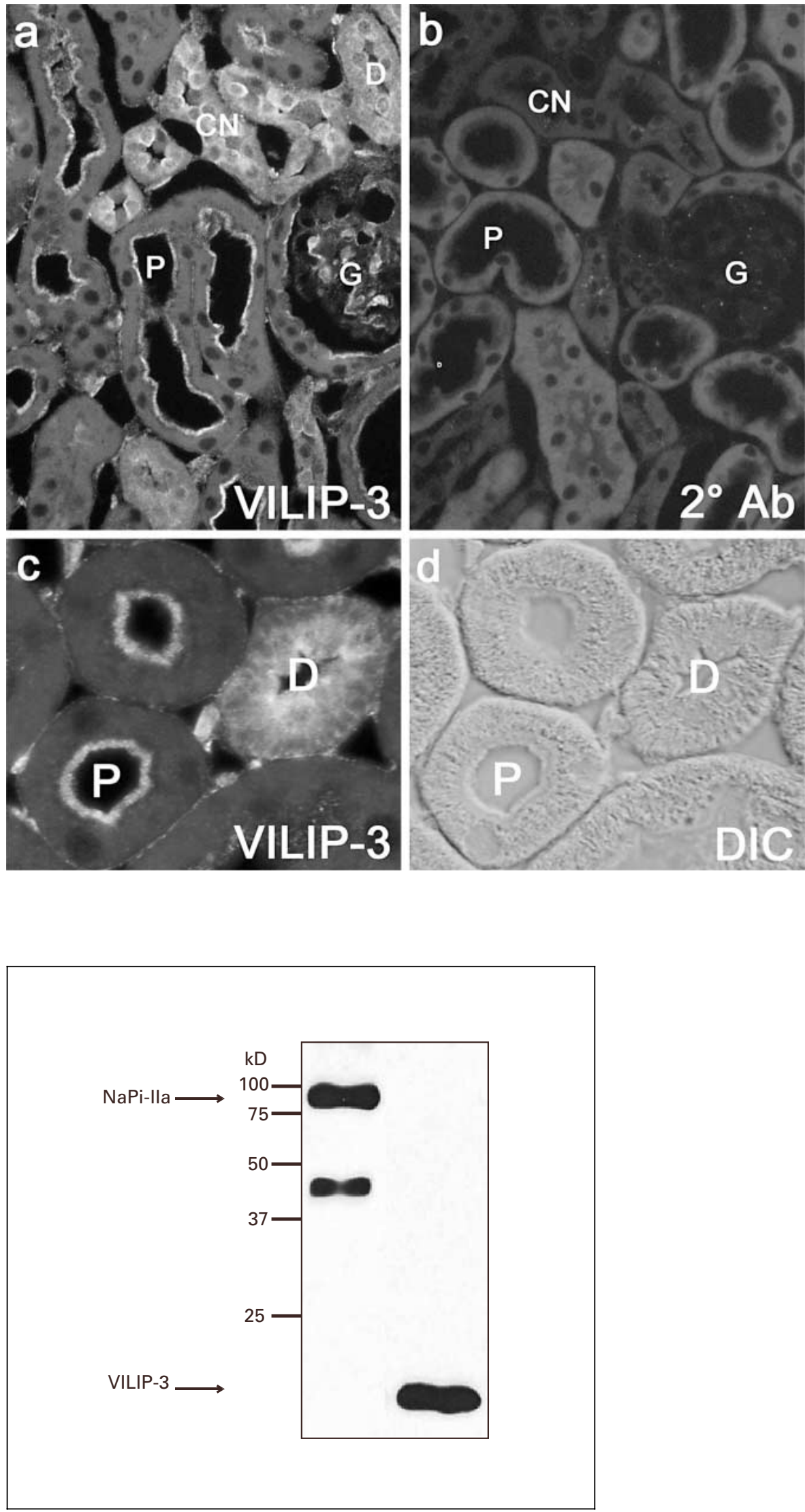

Nephron Physiol 2003;95:p76-p82 

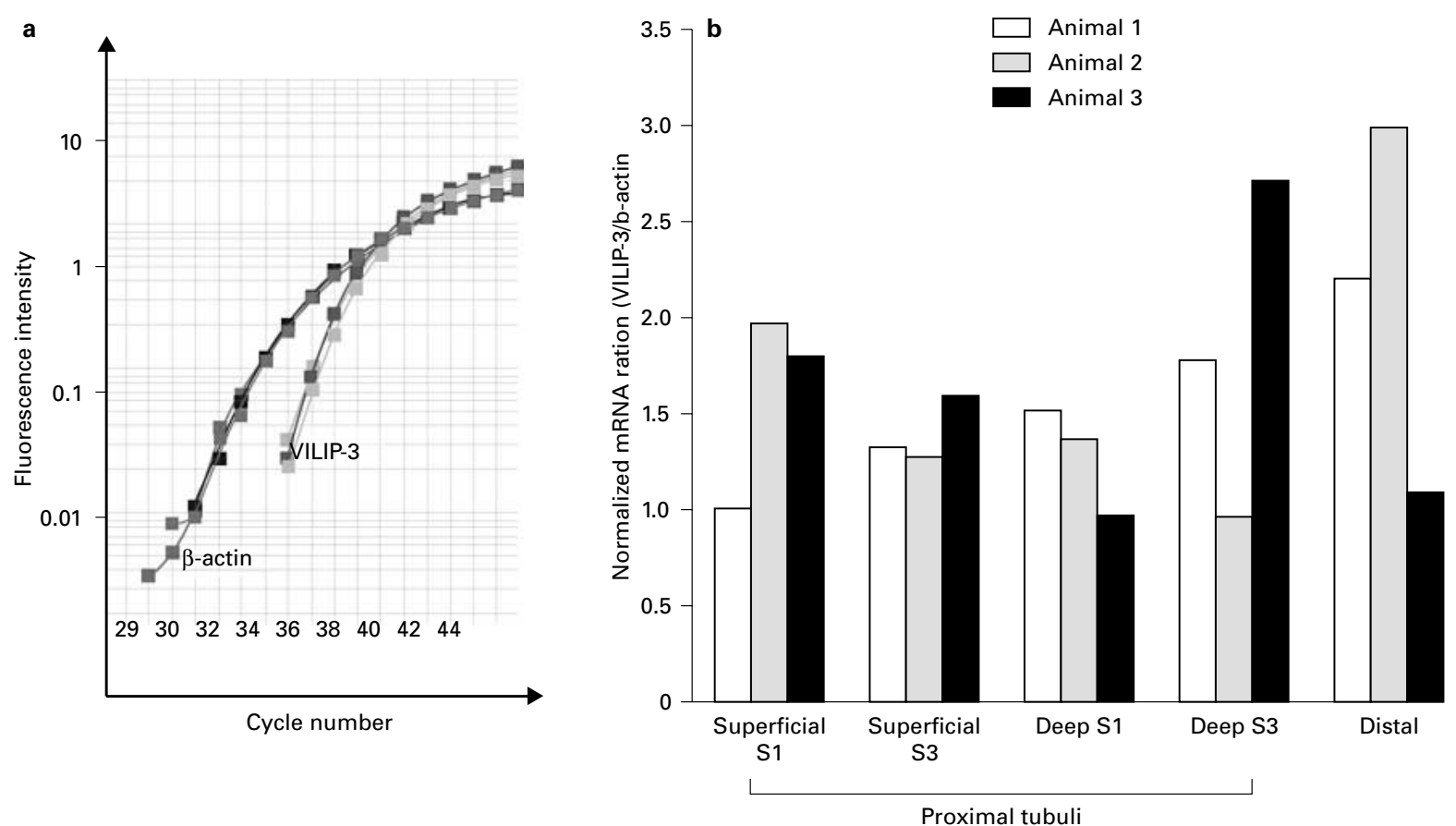

Fig. 4. Expression of VILIP-3 mRNA in proximal and distal tubules of mouse kidney. a Representative real-time PCR amplification curves for VILIP-3 and $\beta$-actin of a deep S1 sample. Each sample was analyzed in triplicate. b S1 and $\mathrm{S} 3$ segments of superficial and juxtamedullary nephrons and distal tubules were isolated by laser-assisted microdissection. Relative quantification of VILIP-3 mRNA was performed by real-time PCR with $\beta$-actin as a housekeeping gene. In all samples tested, the $\mathrm{Ct}$ values for $\beta$-actin were not statistically different.

\section{Discussion}

VILIP-3 was identified based on a yeast two-hybrid screen performed against the amino terminus of the $\mathrm{Na} / \mathrm{Pi}$ cotransporter NaPi-IIa. This interaction was specific as in yeast two-hybrid trap assays no interactions were observed with either the cytoplasmatically oriented carboxy terminus or with the supposed cytoplasmic third intracellular loop of NaPi-IIa.

VILIP-3, a member of NCS, has until now been the least well-known protein of the whole VILIP subfamily. It displays features such as $\mathrm{Ca}^{2+}$ binding (via an EF-hand motif), N-terminal myristoylation, and $\mathrm{Ca}^{2+}$-dependent membrane association [14]. These characteristics are common for the whole NCS protein family, enabling them to interact with the lipid bilayer of the cell membrane and/or target proteins [14, 21, 22]. Although VILIP3 has not been assigned a physiological function yet, it is speculated that it might play a role in cellular signaling pathways [20].

Here, since we found VILIP-3 as a possible NaPi-IIa interacting protein, we focused on the renal expression of VILIP-3 which has not been previously addressed. Strong VILIP-3-mediated immunofluorescence was observed in distal tubuli and collecting ducts and partially colocalized with calbindin D28K. Thus a role for VILIP-3 in these nephron segments can be envisaged as distal tubules play an important role in the renal handling of $\mathrm{Ca}^{2+}[23-25]$. Furthermore, VILIP-3 was localized in the brush borders of proximal tubules where the $\mathrm{Na} / \mathrm{Pi}$ cotransporter $\mathrm{NaPi}$ IIa has been demonstrated to be localized as well [17]. In agreement, VILIP-3 was detected by Western blot in isolated proximal tubular brush border membranes. In order to confirm detection of VILIP-3 by immunological methods real-time PCR was performed with single, laserassisted microdissected proximal $\mathrm{S} 1$ and $\mathrm{S} 3$, as well as dis- 
tal tubular segments. In all samples tested VILIP-3 mRNA could be detected. These data thus suggest that VILIP-3 is expressed and translated along the entire proximal and in the distal tubules.

Although VILIP-3 was identified in a yeast two-hybrid assay as one of the proteins interacting with the amino terminal part of NaPi-IIa, for reasons not known we were not able to confirm this interaction by applying several in vitro assays (pull-down of NaPi-IIa from brush border membrane using GST-fused VILIP-3, or radioactive gel overlays; results not presented). Nevertheless, the proximal tubular apical location of VILIP-3 could suggest a possible role of VILIP-3 in the regulation of the renal $\mathrm{Na}$ / Pi cotransporter NaPi-IIa. In this regard, it is of interest that VILIP-1, a closely related member from the VILIP subfamily, has been shown to influence cell surface expression and/or internalization of a nicotinic acetylcholine receptor in the nervous system [26]. Furthermore, it was shown that VILIP-1 associates with the actin-based cytoskeleton in a calcium-dependent manner [20,22] and that it has modulatory effects on cAMP as well as cGMP signaling [27-29]. Moreover, for VILIP-3 an effect on the MAPK signaling was suggested [20]. Activations of PKA-, PKC- and MAPK-signaling cascades by parathyroid hormone were described to result in the internalization and degradation of NaPi-IIa [30]. Therefore, it is tempting to speculate on a hypothetical role of VILIP-3 in the parathyroid hormone-mediated internalization of the type-IIa $\mathrm{Na} / \mathrm{Pi}$ cotransporter. This remains to be addressed in the future.

\section{Acknowledgements}

This work was supported by the Swiss Natinal Foundations (grant 31-65397.01 to H.M.) and also by the Stiftung für wissenschaftliche Forschung der Universität Zürich.

\section{References}

1 Beck L, Karaplis AC, Amizuka N, Hewson AS, Ozawa H, Tenenhouse HS: Targeted inactivation of Npt 2 in mice leads to severe renal phosphate wasting, hypercalciuria, and skeletal abnormalities. Proc Natl Acad Sci USA 1998;95: 5372-5377.

2 Murer H, Forster I, Hilfiker H, Pfister M, Kaissling B, Lötscher M, Biber J: Cellular/molecular control of renal $\mathrm{Na} / \mathrm{Pi}$-cotransport. Kidney Int 1999;53:S2-S10.

3 Murer H, Hernando N, Forster I, Biber J: Proximal tubular phosphate reabsorbtion: Molecular mechanisms. Physiol Rev 2000;80:13731400 .

4 Biber J: Emerging roles of transporter-PDZ complexes in renal proximal tubular reabsorption. Pflügers Arch 2001;443:3-5.

5 Gisler SM, Stagljar I, Traebert M, Bacic D, Biber J, Murer H: Interaction of the type IIa $\mathrm{Na} / \mathrm{Pi}$ cotransporter with PDZ proteins. J Biol Chem 2001;276:9206-9213.

6 Gisler SM, Pribanic S, Bacic D, Forrer P, Gantenbein A, Sabourin LA, Tsuji A, Zhao Z, Manser E, Biber J, Murer H: PDZK1: I. A major scaffolder in brush borders of proximal tubular cells. Kidney Int 2003;64:1733-1745.

7 Kocher O, Comella N, Gilchrist A, Pal R, Tognazzi K, Brown LF, Knoll JH: PDZK1, a novel PDZ domain-containing protein up-regulated in carcinomas and mapped to chromosome 1q21, interacts with cMOAT (MRP2), the multidrug resistance-associated protein. Lab Invest 1999;79:1161-1170.

8 Hernando N, Déliot N, Gisler SM, Lederer E, Weinman EJ, Biber J, Murer H: PDZ-domain interactions and apical expression of type IIa $\mathrm{Na} / \mathrm{Pi}$ cotransporters. Proc Natl Acad Sci USA 2002;99:11957-11962.
9 Wade JB, Welling PA, Donowitz M, Shenolikar S, Weinman EJ: Differential renal distribution of NHERF isoforms and their colocalization with NHE3, ezrin, and ROMK. Am J Physiol 2001;280:C192-C198.

10 Shenolikar S, Weinman EJ: NHERF: Targeting and trafficking membrane proteins. Am J Physiol 2001;280:F389-F395.

11 Pribanic S, Gisler SM, Bacic D, Madjdpour C, Hernando N, Sorribas V, Gantenbein A, Biber J, Murer H: Interactions of MAP17 with the $\mathrm{NaPi}$-IIa/PDZK1 protein complex in renal proximal tubular cells. Am J Physiol 2003;285: F784-F791.

12 Lambert G, Traebert M, Hernando N, Biber J, Murer H: Studies on the topology of the renal type II NaPi-cotransporter. Pflügers Arch 1999;437:972-978.

13 Loffing J, Loffing-Cueni D, Valderrabano V, Klausli L, Hebert SC, Rossier BC, Hoenderop JG, Bindels RJ, Kaissling B: Distribution of transcellular calcium and sodium transport pathways along mouse distal nephron. Am J Physiol 2001;281:F1021-F1027.

14 Spilker C, Richter K, Smalla KH, ManahanVaughan D, Gundelfinger ED, Braunewell $\mathrm{KH}$ : The neuronal EF-hand calcium-binding protein visinin-like protein-3 is expressed in cerebellar Purkinje cells and shows a calciumdependent membrane association. Neuroscience 2000;96:121-129.

15 Brown D, Lydon J, McLaughlin M, Stuart-Tilley A, Tyszkowski R, Alper S: Antigen retrieval in cryostat tissue sections and cultured cells by treatment with sodium dodecyl sulfate (SDS). Histochem Cell Biol 1996;105:261-267.
16 Biber J, Stieger B, Haase W, Murer H: A high yield preparation for rat kidney brush border membranes. Different behavior of lysosomal markers. Biochim Biophys Acta 1981;647: 169-176.

17 Custer M, Lotscher M, Biber J, Murer H, Kaissling B: Expression of $\mathrm{Na}-\mathrm{Pi}$ cotransport in rat kidney: Localization by RT-PCR and immunohistochemistry. Am J Physiol 1994;266:F767F774.

18 Kajimoto Y, Shirai Y, Mukai H, KunoT, Tanaka C: Molecular cloning of two additional members of the neural visinin-like $\mathrm{Ca}(2+)$ binding protein gene family. $J$ Neurochem 1993;61:1091-1096.

19 Bernstein HG, Baumann B, Danos P, Diekmann S, Bogerts B, Gundelfinger ED, Braunewell KH: Regional and cellular distribution of neuronal visinin-like protein immunoreactivities (VILIP-1 and VILIP-3) in human brain. J Neurocytol 1999;28:655-662.

20 Spilker C, Gundelfinger ED, Braunewell KH: Evidence for different functional properties of the neuronal calcium sensor proteins VILIP-1 and VILIP-3: From subcellular localization to cellular function. Biochim Biophys Acta 2002; 1600:118-127.

21 Béven L, Adenier H, Kichenama R, Homand J, Redeker V, La Caer JP, Ladant D, Chopineau $\mathrm{J}: \mathrm{Ca}^{2+}$-myristoyl switch and membrane binding of chemically acylated neurocalcins. Biochemistry 2001;40:8152-8160.

22 Lenz SE, Braunewell KH, Weise C, NedlinaChittka A, Gundelfinger ED: The neuronal EFhand $\mathrm{Ca}^{2+}$-binding protein VILIP: interaction with cell membrane and actin-based cytoskeleton. Biochem Biophys Res Commun 1996;225: 1078-1083. 
23 Loffing J, Kaissling B: Sodium and calcium transport pathways along the mammalian distal nephrons: From rabbit to human. Am J Physiol 2002;284:F628-F643.

24 Hoenderop JGJ, Nilius B, Bindels RJM: Epithelial calcium channels: From identification to function and regulation. Pflügers Arch 2003; 446:304-308.

25 Nijenhuis T, Hoenderop JG, Nilius B, Bindels RJ: (Patho)physiological implications of the novel epithelial $\mathrm{Ca}(2+)$ channels TRPV5 and TRPV6. Pflügers Arch 2003;446:401-409.
26 Lin L, Jeanclos EM, Treuil M, Braunewell KH, Gundelfinger ED, Anand R: The calcium sensor protein visinin-like protein-1 modulates the surface expression and agonist sensitivity of the alpha 4beta 2 nicotinic acetylcholine receptor. J Biol Chem 2002;277:41872-41878.

27 Braunewell KH, Gundelfinger ED: Low level expression of calcium-sensor protein VILIP induces cAMP-dependent differentiation in rat C6 glioma cells. Neurosci Lett 1997;243:139142.

28 Braunewell KH, Spilker C, Behnisch T, Gundelfinger, ED: The neuronal calcium-sensor protein VILIP modulates cyclic AMP accumulation in stably transfected C6 glioma cells: Amino-terminal myristoylation determines functional activity. J Neurochem 1997;68: 2129-2139.
29 Braunewell KH, Brackmann M, Schaupp M, Spilker C, Anand R, Gundelfinger, ED: Intracellular neuronal calcium sensor (NCS) protein VILIP-1 modulates cGMP signalling pathways in transfected neural cells and cerebellar granulae neurones. J Neurochem 2001;78:12771286.

30 Bacic D, Schulz N, Biber J, Kaissling B, Murer $\mathrm{H}$, Wagner CA: Involvement of the MAPKkinase pathway in the $\mathrm{PTH}-$ mediated regulation of the proximal tubule type IIa $\mathrm{Na} / \mathrm{P}$ cotransporter in mouse kidney. Pflügers Arch 2003;446:52-60. 